\title{
The use of abbreviations by superscript letter in an early fifteenth-century manuscript of the Wycliffite Bible*
}

\author{
Joanna Grzybowska \\ John Paul II Catholic University of Lublin, Poland
}

\begin{abstract}
The use of scribal abbreviations in medieval manuscripts was mainly dictated by the need to save space and time as the creation of a medieval book was both extremely costly and time-consuming. One of the types of scribal abbreviations used in medieval manuscripts is abbreviation by superscript letter. In this type of abbreviations one superscript letter indicates the ending of a given word, or, in some cases, a medial position. Both vowels and consonants were used as abbreviations by superscript. They usually denoted, apart from the actual letter written in superscript, the preceding vowel or the letter $<\mathrm{r}>$. According to Cappelli (1929/1982), superscript letters in Latin were used mainly in word-final positions; however, it was not uncommon for a superscript vowel to appear wordmedially.

The main objective of this paper is to investigate the use of superscript letters in an early fifteenth-century manuscript of the Wycliffite Bible (Mscr.Dresd.Od.83) on the basis of the Gospel of Matthew. Within the manuscript there are both superscript consonants and vowels. However, in some cases these abbreviations seem to appear in very specific contexts, whereas in other cases the contexts allowing the abbreviations to appear are much broader. The possible reasons behind this situation will be discussed within this paper along with the correspondence between the superscript letter and the spelling conventions used within the manuscript.
\end{abstract}

Keywords: superscript letter, Wycliffite Bible, scribal abbreviation, medieval manuscript

\section{Introduction}

The main objective of this paper is to investigate the use of abbreviations by superscript letter in the Dresd.Od.83 manuscript of the Wycliffite Bible, the problems connected to the classification of these abbreviations, and spelling issues connected to expanding them.

One of the most striking phenomena that characterise medieval manuscripts were scribal abbreviations. They can be treated as scribe's intervention to the original text as they can be

\footnotetext{
* I would like to thank Professor Magdalena Charzyńska-Wójcik for all her comments on this paper.
} 
often expanded in more than one way, which, in turn, may lead to possible misinterpretations. The main purpose for using abbreviations was the need to save time and space, as the process of creating a medieval codex was time-consuming and required the use of expensive materials. The number of scribal abbreviations increased with time and, by the Late Middle Ages, created a complex system. Scribes abbreviated both whole words and letters.

\subsection{The system of scribal abbreviations in Late Middle Ages - An overview}

The practice of using abbreviations by scribes is older than Christianity and can be traced back to the Roman times, when, for instance, legal formulae as well as first names were abbreviated in inscriptions (Bischoff, 1986/2012, p. 150). The fall of the Western Roman Empire contributed to the disappearance of the universal style of writing and, consequently, to the disappearance of the common way of abbreviating letters in manuscripts, which led to regional divisions and, therefore, confusion.

In the Early Middle Ages, the abbreviations used by scribes differed depending on the region of Europe the scribes came from. Another turning point in the history of scribal abbreviations came with the reign of Charlemagne, who introduced several reforms into the writing system (Bischoff, 1986/2012, p. 114). The so-called Carolingian reform worked as a unifying factor in the system of scribal abbreviations (Bischoff, 1986/2012, p. 154). It seems that Charlemagne was especially concerned about the state of biblical manuscripts, as he did not allow young men who were training to be a scribes to copy the Scripture (Kenyon, 1895/1898, p. 182). What is more, he extended an invitation to Alcuin, a monk from England, who was asked to create a corrected version of Vulgate (Charzyńska-Wójcik, 2013, p. 14; Kenyon, $1895 / 1898$, p. 182). It is important to mention that the Carolingian 'renovatio' concerned many different areas of learning. Within the biblical manuscripts Alcuin was mainly concerned with correcting the orthography as well as the organisation of the text on the manuscript page (McKitterick, 2005, p. 155). The scribes started using the standardised writing style (later called the Carolingian minuscule) and abbreviation system (Bischoff, 1986/2012, p. 154). When it comes to the system of abbreviations, the regional differences were reduced and the amount of scribal abbreviations started to correlate to the status of the copied text - the higher the status, the smaller amount of abbreviations was used (Bischoff, 1986/2012, p. 154).

The system of scribal abbreviations seemed to be quite stabilised by the end of the eleventh century, even though scribes still added new abbreviations to it. The number of scribal abbreviations used in manuscripts grew steadily throughout the medieval period to become fully developed by the High Middle Ages. The Late Middle Ages can be seen mainly as a period of consolidating and refining the system.

Bischoff (1986/2012, p. 156) argues that because of the clarity of the system at the end of the medieval period, it is possible to divide the abbreviations into four groups: abbreviations using conventional signs, suspensions, contractions and syllabic abbreviations. At the same time, a different way of classifying scribal abbreviations is proposed by Cappelli (1929/1982, p.1), who claims that they can be divided into: "truncations, contractions, abbreviation marks significant in themselves, abbreviation marks significant in context, superscript letters and 
conventional signs". This difference in classification may stem from the fact that, even though the system of abbreviations seemed quite stabilised and uniform by the end of the medieval period, it still varied between scribes or scriptoria. However, the term "syllabic abbreviations" seems to be quite unclear and misleading because other groups of abbreviations mentioned by Bischoff (1986/2012) can be used, in some contexts, to abbreviate syllables. For example, the so called 9-mark (9), which is classified as a conventional sign, abbreviates sequences of letters $<$ con $>$ and $<$ cum $>$. Therefore, for the sake of this study, it seems best to use the division proposed by Cappelli (1929/1982).

Truncations, according to Cappelli (1929/1982, pp. 1-7), are types of abbreviations in which only the first part of the word is spelled out and the abbreviation mark replaces the final letters. The missing part of the word can be abbreviated either by general signs (e.g. macrons) or specific truncation signs, which state precisely what kind of letters are abbreviated.

Contractions, on the other hand, are the type of abbreviations in which an abbreviation mark, usually a macron, stands for one or more of the middle letters, which is why abbreviations by contraction can be classified as abbreviations of whole words. Paoli (1891; as cited in Cappelli, 1929/1982, p. 7) claims that abbreviations by contraction can be divided into pure contractions, in which only first and last letters are spelled out, and mixed contractions, in which also middle letters are spelled out. Among abbreviations by contraction are both nomina sacra and abbreviations of hierarchical terms (e.g. 'episcopus').

Abbreviation marks significant in context are a type of abbreviation which represents different letters depending on the letters which appear closest to it (Cappelli, 1929/ 1982, p. 18). For instance, when the so-called 3-mark 3 follows the letter $<0>$, it usually stands for $<-$ nem $>$, but it can also stand for the letter $\langle\mathrm{m}\rangle$. However, in Roman cursive from the twelfth century the 3-mark usually stands for the letters <-rum> and is written at the same level with other letters within the line (Cappelli, 1929/1982, p. 22). Interestingly, this abbreviation mark may correspond to 'macron', which also stands for the letter $<\mathrm{m}>$. This shows that two different abbreviation marks sometimes could represent the same letter. To slightly complicate matters, the opposite situation was also possible.

Among the abbreviations described by Cappelli (1929/1982) there are abbreviation marks significant in themselves. It is a type of abbreviation mark which does not change its meaning depending on the context it appears in (Cappelli, 1929/1982, p. 13). A good example of this type of abbreviation is a macron, which was used both as an abbreviation for the letters $<\mathrm{m}>$ and $<\mathrm{n}>$ and an abbreviation of two adjoining syllables with the letters $<-\mathrm{i}->$ and $<-\mathrm{o}->$ in words such as 'finis', 'hominis' or 'honorem' (Bischoff, 1986/2012, p. 158).

The next group of abbreviations used by medieval scribes are represented by superscript letter - a type of abbreviation in which a letter written above a consonant indicates the ending of a given word. Scribes used both vowels and consonants as superscript letter. Superscript vowels can stand for both the vowel and for that vowel and the letter $<r>$ (Cappelli, 1929/1982, p. 30). For instance, superscript $<\mathrm{a}>$ and $<\mathrm{i}>$ could stand respectively for $<$-ra $>$ and $<$-ri $>$ as illustrated in: 'su $p^{a}$ ' for 'supra' or ' $p^{i}$ or' for 'prior' (Bischoff, 1986/2012, p. 159). Superscript consonants were generally used in a similar way to vowels and abbreviated both the consonant and the preceding vowel. 
Abbreviations using conventional signs include abbreviation marks which are not recognizable as letters and, according to Cappelli (1929/1982), are used as isolated signs used instead of a well-known word or phrase. As examples of this type of abbreviations Cappelli (19929/1982, p. 39) shows signs 9 and J, which stand for the Latin words (and prefixes) con and cum.

\subsection{Manuscripts of the Wycliffite Bible}

The term 'Wycliffite Bible' is, in fact, a term which can be assigned to two translations of the Bible. The first version of Wycliffe's Bible, usually referred to as the Early Version, was created in the year 1380 and it was the translation of the New Testament. Two years later, in 1382, a translation of the whole Bible was completed (Kenyon, 1895/1898, p. 200). The second version, often called the Late Version, was most likely created around 1388. This revision of the first translation was not as literal as the Early Version. It is argued by Norton (2000, p. 7) that the translators "moved towards a more readable English rendering, one more obviously capable of standing by itself without reference back to the Latin".

When it comes to the manuscripts of the Wycliffite Bible, it is important to mention that quite a large number of them survived, even though the copies of Wycliffe's Bible were systematically destroyed due to being claimed as heretical. The notion that the Wycliffite Bible was associated with heresy is connected to the fact that Wycliffe openly expressed his reformatory views on doctrinal matters which were not supported by the Pope or church dignitaries. In effect, Wycliffe's works were often not in accordance with the teaching of the Church. In fact, Wycliffe's first quarrel with ecclesiastical authorities was connected with the Pope's demands for tribute money, which were refused by the Parliament in 1366 (Kenyon, $1895 / 1898$, p. 199). In the year 1378 Wycliffe wrote the treatise De Potestate Papae, which pointed to the Scripture as the sole source of doctrine and, therefore, it undermined the authority of the Pope (Metzger, 2001, p. 56). What is more, De Civili Dominio, another of Wycliffe's works, resulted in Wycliffe facing charges of heresy and, in the end, condemnation by the Pope (Ghosh, 2004, p. 22) As is stated by Estep (1986, p. 66), one of Wycliffe's claims, condemned by Gregory XI, was the denial of transubstantiation, one of the key dogmas of the Church. Wycliffe claimed that transubstantiation was impossible from both logical and metaphysical point of view (Olson, 1999, p. 358).

Wycliffe's opposition towards some of the dogmas of the Church resulted in the ban on the Wycliffite Bible issued 1408 (Deanesly, 1920, p. 131). However, it should be mentioned that translating the Bible into a vernacular language was not generally prohibited, because translations into French were common in the pre-Wycliffite times (Deanesly, 1920, p. 206). The official condemnation of the translation did not seem to influence its status among the readers. Interestingly, Poleg (2013) argues that it is possible to find formal similarities between many manuscripts of the Wycliffite Bible and those of the Latin Vulgate - similarities which point to the need for an English translation within the orthodox community. At the same time, " $t]$ he removal of the General Prologue and of marginal glosses dissociated Wycliffite Bibles from the realm of Lollard thought, while simultaneously supporting an unmediated access to the biblical 
text" (Poleg, 2013, pp. 90-91). It meant that the Wycliffite Bible was read not only by Lollards, but also by other people, who wanted to gain better understanding of the Bible.

\section{Analysis of superscript letters in the Dresd.Od.83 manuscript of the Wycliffite Bible}

\subsection{Methodology}

The analysis of abbreviations by superscript letter is based on my own transcript of the Gospel of Matthew from the Dresd.Od.83 manuscript of Wycliffe's Bible. The transcript consists of 24620 words (100 060 characters, excluding spaces). The transcript was prepared with the view to representing the manuscript as accurately as possible with respect to all scribal conventions. Obviously all abbreviations were expanded but the expanded sequences were subsequently italicised ${ }^{1}$. Another convention used while preparing the transcript concerns the use of punctuation. The system of punctuation marks used in the transcript reflects the one used by the scribe. Another editorial decision made while preparing the transcript of the Gospel concerned the letters used in the manuscript. In the manuscript there are some letters, namely 'thorn' and 'yogh', which are remnants of the Old English alphabet. Both of these letters are used in transcript, however, it is important to mention that the 'thorn' used in the manuscript does not have an ascender (which it used to have in the Anglo-Saxon times). ${ }^{2}$

After preparing the transcript, all abbreviations were extracted and grouped according to the letters they represented. Afterwards, the occurrences for each group were counted. All contexts which excluded abbreviations were also catalogued just as those in which the use of an abbreviation was permitted by the context but the scribe wrote the word in full.

\subsection{Description of the Dresd.Od.83 manuscript of the Wycliffite Bible}

The Dresd.Od.83 manuscript of Wycliffe's Bible is dated back to $1400^{3}$. Currently it is held in the Sächsische Landesbibliothek - Staats - und Universitätsbibliothek Dresden (SLUB Dresden). The manuscript contains selected books of the Bible: the Gospels, the Epistles, the Book of Revelation as well as Jerome's prologues to these books. What is more, the manuscript contains the Calendar of Gospel Readings and the Readings from the Old Testament.

The manuscript is written on parchment. Its measurements ${ }^{4}$ are $17 \times 12 \mathrm{~cm}$. The first page of each book is illuminated with flowers, whereas other pages are not. It is important to mention that flower motifs in illumination are often used in the manuscripts of that century (Fisher, 2004, p. 5). When it comes to the first pages of individual chapters, the decoration is limited to red lines starting from the blue initial.

1 Because all abbreviations are marked in italics, all lexical items within this article are given in single quotation marks

2 In effect, the thorn used in the analysed manuscript is similar to another letter used in Old English texts, namely 'wynn' $<p>$. It is important to realise, however, that the similarity is purely visual and does not imply an affinity of any other type.

3 According to the information provided by SLUB Dresden.

4 According to the information provided by the SLUB Dresden. 
The text is written in two columns with initials and pilcrows written in blue ink. The 'capitula' are also written in blue ink and they are followed by red abbreviations of the evangelist's name. The manuscript is written in gothic textura, a type of script used by scribes in the High and Late Middle Ages, which could be characterised by angular shapes of letters (Bischoff, 1986/2012, pp. 133-134). Another feature of the script used in the manuscript is the joining of letters, especially $<\mathrm{m}>,<\mathrm{n}>$ and $<\mathrm{u}>$, which consist of either two or three minims. The scribe differentiates between lower and upper case letters. However, it is important to mention that capitalisations are used inconsequently.

Scribal mistakes can be observed throughout the manuscript; however, most of these errors were corrected by the original scribe (the script used by the scribe who corrected the mistakes is exactly the same as the one used by the original scribe). It is necessary to mention that scribal mistakes are intrinsic features of manuscripts, which were caused by the way medieval manuscripts were produced.

\subsection{Abbreviations by superscript letter in the Dresd.Od.83 manuscript of Wycliffe's Bible}

Cappelli (1929/1982, p. 30) claims that abbreviation by superscript letter is an abbreviation in which the superscript letter stands for the missing letters at the end of the word. The superscript letters can be both vowels and consonants. Within the Gospel of Matthew of the Dresd.Od.83 manuscript of the Wycliffite Bible the scribe used four different superscript letters. They indicated seven different sequences of letters. What is more, the superscript letters used within the manuscript can be divided into certain groups.

\subsubsection{Superscript $<\mathrm{t}>$}

Superscript $<\mathrm{t}>$ can be expanded into four different sequences of letters: $<$ at $>,<$ ut $>,<$ ot $>$ and $<$ ip $>$. Examples of use of those abbreviations are shown in (1) below.

(1) a. verse 5.39 "But I seie to zou. pat ${ }^{5}$ ze azenstonde not an yuel man"

b. verse 3.15 "but iesu answeride and seide to him/ Suffre now/For pus it fallip to us to fulfille al riztfulnes/"

c. verse 9.36 And he siz pe peple. and hadde rupe on hem; for pei weren trauelid; and liggynge as scheep not hauynge a scheepherde/"

d. verse 13.17 "pat pe profecie of isaie seiyn=ge. be fulfillid in hem; wip heeringe ze schulen heere; and ze shulen not vndir=stoned/ and ze seynge schulen se; and ze shulen not se/"

It is important to mention that a superscript $<\mathrm{t}>$ may appear in all positions within the line of a manuscript; it is not restricted to the margin. At the same time, it can also be noticed that it is used only in the word-final position. The Figure 1 below shows the number of occurrences of each sequence of letters abbreviated by superscript letter $<\mathrm{t}>$.

\footnotetext{
5 The underlined words illustrate the use of superscript letters within the context of a verse.
} 


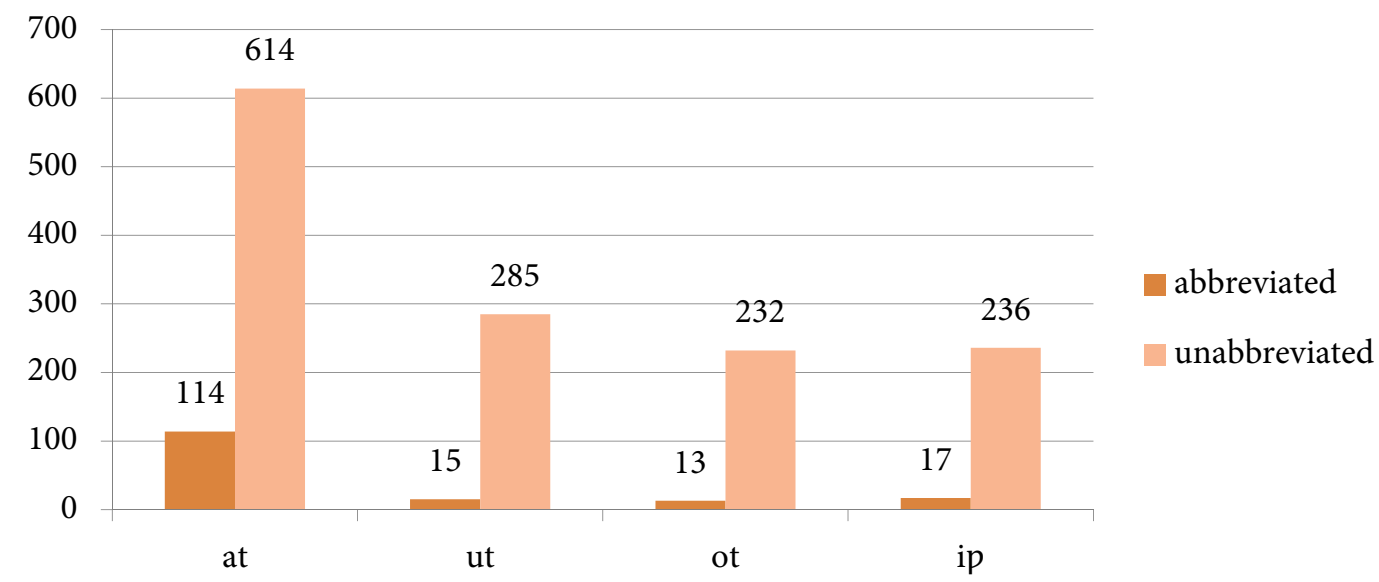

Figure 1: Abbreviation for letters $\langle$ at $\rangle|\langle u t\rangle|\langle o t\rangle \mid\langle i p\rangle$

It is important to mention that superscript $<\mathrm{t}>$ does not appear in equal numbers in all contexts. Another important fact connected to this superscript letter is that it appears in strictly specified contexts, to the effect that it is limited to specified words. For instance, when it represents the letters <at $>$, the abbreviation appears only in the word 'pat'. The abbreviation for the letters $<$ ut $>$ appears in the word 'but', for <ot $>$ - 'not' and for <ip $>$ - in the word 'wip'. The sequence of letters <ip $>$ stands out from the remaining sequences abbreviated by this sign. In this case, the sequence of letters abbreviated by the letter $<\mathrm{t}>$ does not contain this letter in it and deserves a more detailed description.

As mentioned in Section 2.1., the scribe used the letter 'thorn' $\langle p\rangle$ in the manuscript. In fact, there seems to be a preference for this letter in comparison with $<$ th $>$. Within the Gospel of Matthew there are 3783 occurrences of $<p>$ and only 79 occurrences of $<$ th $>$. The examples in (3) and (4) present some of the contexts in which $<$ th $>$ and $<p>$ appear.

(3) a. verse 1.3 "Iudas bigat Fares and zaram of Tha $=\underline{\mathrm{mar}}$ / Fares bigat esrom/"

b. verse 1.13 "Zorobabel bi=gat $\underline{\text { Abiuth/ }}$ Abiuth bi=gat Eliachym/Eliachim bigat Asor/"

c. verse 2.6 "and pei seiden to him/In beth=leem of Iuda/ for so it is writen bi aprofete"

(4) a. verse 1.1 "The book of pe ge=neracioun of iesu crist pe sone of dauip. pe sone of Abra=ham/"6

b. verse 2.4 "But king eroude her=de/ and was troublid; and al ierusalem wip him/"

c. verse 4.3 "and pe temptere cam nyz: and seide to him/ If pou art g=oddis sone; seie pat pese stoones be maad looues/"

It can be deduced from the examples provided in (3) and (4) that the $<$ th $>$ sequence seems to be used more often with proper names, whereas $\langle p\rangle$ is used more often in other contexts. This is supported by the numbers presented in Figure 2 below. It is additionally interesting because the digraph $<$ th $>$ seems to appear mostly in proper names, which simultaneously constitute words of foreign origin. The digraph appears 46 times in proper names (such as 'Obeth', 'Joathan', 'bethleem' or 'sathanas'), and 33 times in other words (mostly in the word 'the' - 19 times). It is important to mention that eight instances of $<$ th $>$ appear in words beginning with a capital letter both in proper names, for example 'Thamar', and in words like 'the' or 'therfore',

6 The $<$ th $>$ sequence in this verse is used probably due to the illumination of letter $<\mathrm{t}>$ as it is the first verse of the Gospel of Matthew. 
when they appear at the beginning of a verse or chapter. It seems significant especially in comparison with the letter $\langle\mathrm{p}\rangle$, which appears only once within a proper name - 'Dauip'.

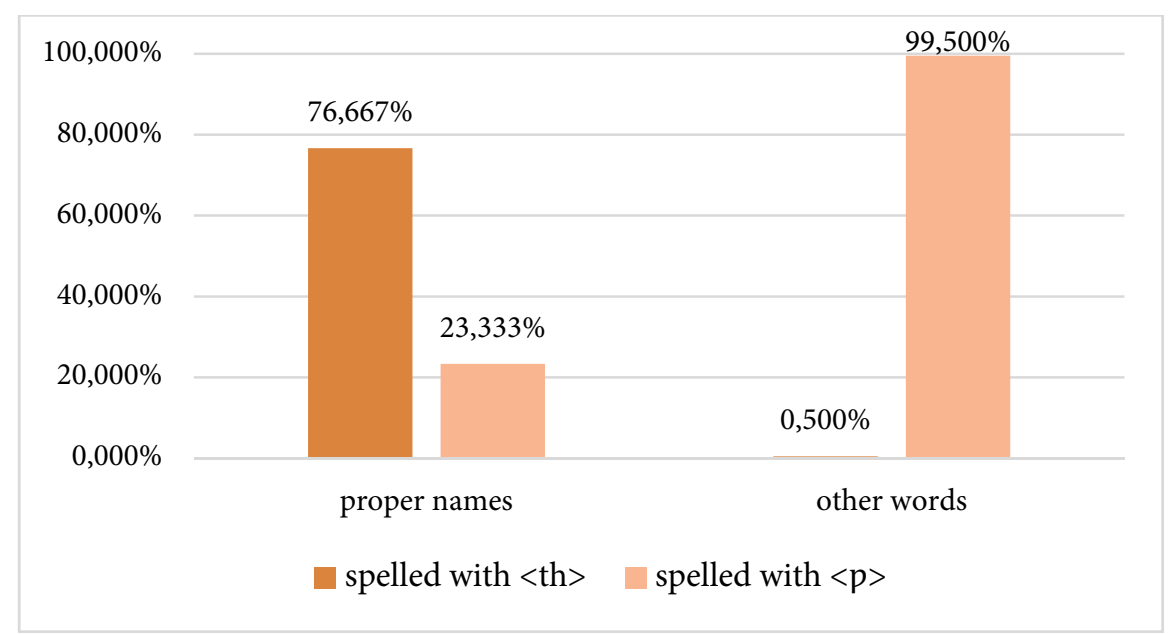

Figure 2: Percentage of Proper Names and Other Words Spelled with Letters $<$ th $>$ and $<p>$

Therefore, the fact that superscript $<t>$ was used by the scribe to abbreviate the ending of the word 'wip' seems surprising. The scribe's choice to use superscript $<\mathrm{t}>$ in this context, instead of a different type of abbreviation does not correspond to the spelling of the word 'wip' within the manuscript. In fact, there is only one instance of 'with' spelled with a digraph in the manuscript - verse 20.20: "g panne pe modir of pe sones of ze=bedee came to him with hir sones honourynge. and axynge sum ping of him/". In comparison, the unabbreviated word 'wip', spelled with the thorn, appears 122 times within the Gospel of Matthew.

Therefore, a question arises about the relationship between $\langle$ th $\rangle$ and $\langle p\rangle$ in the manuscript, especially, because there seems to be no clear reason for using superscript $\langle t\rangle$ as an abbreviation for the statistically preferred letter $\langle p\rangle$. However, it should be mentioned that $<p>$ is a runic character and, because of that, does not belong to the same writing system as the purely Latin scribal abbreviations. Therefore, it is possible that the scribe chose letter $<\mathrm{t}\rangle$ because the context excluded $<\mathrm{p}>$. In fact, there are several instances of digraph $<$ th $>$ appearing in contexts excluding the appearance of the thorn (for example, initials, beginnings of chapters).

\subsubsection{Superscript $<\mathrm{s}>$}

The next abbreviation of this type is superscript $<$ s $>$, which stands for the sequence of letters $<$ is $>$. The examples shown in (5) represent all types of contexts, in which this abbreviation appears.

(5) a. verse 6.2 "nyle pou trumpe bifore pee as y=pocritis doon in synagogis"

b. verse 22.4 "Eftsoo=nes he sente opere seruaun=tis; and seide/ Seie ze to pe men pat ben beden to pe feeste/ lo I haue maad re=di my mete; my bolis and my volatilis ben slayn. and alle pingis ben redy; come ze to pe weddingis/"

c. verse 24.3 "And whanne he satt on pe hil of olyuete; hi=se disciplis camen to him priuyli and seiden/ Seie to us whanne pese pingis schulen be; and what toke=ne of pi comynge. and of pe eendinge of pe world/" 
d. verse 24.30 " and panne pe toke=ne of mannes sone $\mathrm{sc}=\mathrm{hal}$ appere in heuene; and panne alle kynredis of pe erpe schulen wei=le and pei schulen se man=nes sone comynge in pe cloudis of heuene; wip miche vertu and maies=te/"

e. verse 26.60 "and pei founden not; whanne manye fals witnessis weren comen/ But at pe laste two false wit=nessis camen;"

f. verse 6.12 "and forzeue to vs oure dettis. as and we forzeuen to oure dettouris/"

g. verse 7.24 "perfore ech man pat heerip pese my wordis and doip hem; schal be maad lijk to awiseman pat hap bildid his hous on astoon."

h. verse 9.4 "and whanne iesu hadde seen her pouztis. he seide/ wherto penken ze yuel pingis in zoure hertis.?"

i. verse 13.16 "But zoure izen pat seen ben blessid; and zoure eeris pat heeren/"

j. verse 15.15 "Petir answeride; and seide to him/ Expowne to us pis parable/"

k. verse 25.19 "For of pe herte goon out yuele thouztis. mansleyngis. auoutries. fornicaciouns. peftis. fals witnessingis. blasfemies/"

1. verse 21.41: "And pei seien to him/ He schal lese yuel. pe yuel men/ and he schal sette to hire his $\mathrm{vy}=$ nezerd to opere erthetilieris; whiche schulen zelde fruitis to him in her tymes/"

In the Gospel of Matthew superscript $<\mathrm{s}>$ appears fifteen times in twelve different words. This differentiates it from superscript $<t>$, which was lexically restricted depending on the sequence of letters it stood for. However, there is also another difference between this abbreviation and the previous one. Whereas superscript $<t>$ may appear in any position within the line of the manuscript, superscript $<\mathrm{s}>$ seems to be used only at the end of a line. Therefore, it appears that the scribe chose to use the abbreviation only in places where using the unabbreviated sequence of letters would disrupt the composition of the page. All 15 occurrences of superscript <s> appear near the margin, where the use of the unabbreviated form would result in lengthening the line and, in that way, disrupting the way the page looks.

\subsubsection{Superscript $<\mathrm{u}>$}

The third superscript vowel used within the manuscript is $<\mathrm{u}>$, which stands for sequence of letters $<\mathrm{ou}>$. The examples in (6) show the contexts in which the abbreviation appears within the manuscript.

(6) a. verse 19.19 "He seip to him; whiche/ And iesus seide/ pou schalt not do mansleyin=ge; pou schalt not do a=uoutrie. pou schalt not do pefte pou schalt nott seie fals witnessyynge."

b. verse 5.32 "But I seie to zou. pat eueri man pat leeuep his wijf. outtaken cause of fornicacioun; makip hir to do letcherie/ and he pat weddip peforsaken wijf; doip auoutrie/"

c. verse 14.21 "And pe noumbre of men pat eeten was fyue pou=sand of men; outaken wymmen and litil children/"

The abbreviation appears 30 times within the Gospel of Matthew out of 219 occurrences of this sequence of letters. Interestingly, it is the only superscript letter which appears word-medially. However, it should be mentioned that the word 'pousand' which the superscript $<\mathrm{u}>$ appears in was divided by the scribe in order to preserve the layout of the page. 


\subsubsection{Superscript $<\mathrm{e}>$ and $<\mathrm{o}>$}

The next abbreviation by superscript letter is superscript $<\mathrm{e}>$, which stands for the sequence of letters <ee $>$. The examples shown in (7) present the use of this abbreviation in the Dresd.Od.83 manuscript.

(7) a. verse 6.4 "pat pin almes be in hid=lis and pi fadir pat seep in hid=lis. schal quite pee/"

b. verse 8.13 "And iesus seide to pe cen=turioun/go; and as pou hast bileeued. be it doon to pee/ and pe child was heelid fro pat hour"

c. verse 9.22 "and iesu turned and siz hir and seide/ Douztir haue pou trist; pi feip hap maad pee saaf/ and pe womman was hool fro pat hour/"

d. verse 26.11 so fadir; for so it was plesinge tofore peel

There are 15 occurrences of that abbreviation; all of them appear in the word 'pee'. It is especially interesting, because there seem to be other words, in which the abbreviation could appear in, for example 'zee', 'tree', 'galilee', or 'iudee' yet it is not attested there.

The fact that superscript $<\mathrm{e}>$ appears only within one word poses the question whether this sign abbreviates a sequence of letters, as the previously mentioned superscript $\langle\mathrm{t}\rangle$ and $\langle$ s $\rangle$ do, or whether the $\mathrm{p}^{e}$ sign should be treated as an abbreviation of a whole word. However, it is possible to explain why superscript $<\mathrm{e}>$ does not appear in the context of other words without assuming it is an abbreviation for the whole word. One explanation might be that the scribe chose to use a different abbreviation to express <ee $>$. For example, in other words ending with the letters <ee $>$ there is a letter ' $r$ ' preceding them, which means the whole sequence of letters $<$ ree $>$ can be abbreviated by the mark? written above the preceding letter. The only exceptions seem to be the words like 'zee', 'citee', 'galilee' and 'iudee'. However, when it comes to proper names like 'galilee' or 'iudee' the scribe usually chooses not to abbreviate them or use an abbreviation for the whole word - a contraction or an abbreviation mark significant in itself (Section 1.1.). Although, the fact that the scribe chose to use this abbreviation in a single word could suggest classifying it as abbreviation for the whole word rather than for a sequence of letters, the clarity of the system should be taken into consideration - a matter I will return to in the concluding section.

The superscript letter with the smallest number of occurrences is $\langle 0\rangle$. It represents the sequence of letters $<$ ro $>$. The examples in (8) show the use of this abbreviation within the manuscript.

(8) a. verse 4.21 "and he zede forp fro pat place; and he siz tweze opere briperen. James of ze=bede and Ioon his bropir. in a schip wip zebede her fadir amendinge her nettis/ and he clepide hem/"

b. verse 24.29 " And anoon aftir pe tribulacioun of po dai=es; pe sunne schal be maad derk; and pe moone schal not zeue hir lizt; and pe sterris schulen falle fro heuene. and pe vertues of heuenes schulen be $\mathrm{mo}=\mathrm{ued} / "$

Interestingly, superscript $<0>$ is used only twice as an abbreviation for the ending of the word 'fro'. This shows a huge disproportion in comparison with the 99 occurrences of unabbreviated word 'fro'. It seems, however, that the abbreviation is restricted to the position at the end of a line (before the margin) as it never appears in the middle of the line. Another reason behind the fact that the scribe did not use the abbreviation in any other context might be that there is no 
other word within the Gospel of Matthew which ends with the sequence of letters <ro $>$. Moreover, a very similar sign is used by the scribe to indicate the beginning (number) of a new

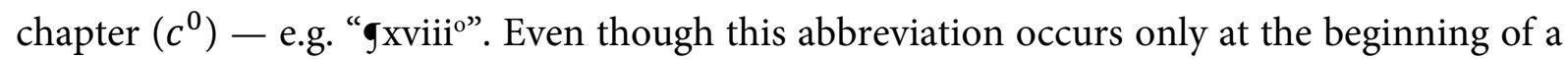
chapter and is written in red ink, the graphic similarities between it and superscript $<0>$ could potentially cause some misunderstandings.

\section{Conclusions}

To sum up, the abbreviations by superscript letter used in the Dresd.Od.83 manuscript of the Wycliffite Bible are not a homogenous group. They can be divided into three categories depending on how they are used within the manuscript.

The first type of abbreviation, superscript $\langle\mathrm{t}\rangle$, represents the largest amount of the sequences of letters: $<$ at $>,<$ ut $>,<$ ot $>$ and $<$ ip $>$. They appear in very restricted contexts; each of them is used only in one specific word, for example 'but' or 'pat'. The second type, superscript $<\mathrm{s}>$, differs quite significantly from superscript $<\mathrm{t}>$. Although it represents only one sequence $-<$ is $>$, it is used in many words. The first superscript vowel discussed in this paper $-<\mathrm{u}>$ stannds for one sequence of letters - <ou $>$. It appears in three contexts, in words 'zou', 'pou' and 'pousand'. It is the only superscript letter which appears word-medially; however, it should be noticed that even in this context, the abbreviation appears near the margin, as the word 'pousand' was divided by the scribe. The next group of superscript letters contains superscripts $<\mathrm{e}>$ and $<\mathrm{o}\rangle$. They represent only one sequence of letters each and appear in strictly specified contexts. Even though, at first, it may seem that these abbreviations were used differently than the two other superscript letters, they should not be categorised as abbreviations of whole words. This is mainly connected to the fact that, within the Gospel of Matthew, there are either no other words which would provide the suitable context for the appearance of a superscript letter (for example, sequence $<$ ro $>$ abbreviated by superscript $<0>$ ) or there are other abbreviations which may be used in place of the superscript (for instance, sequence of letters $<$ ree> or words such as 'galilee'). Throughout the Gospel of Matthew, a clear division can be observed between abbreviations which can be classified as abbreviations of whole words and those which represent abbreviations of letters or sequences of letters. All other abbreviations of whole words within the manuscript are either contractions (e.g. 'nomina sacra') or "abbreviation marks significant in themselves" (for example \&). What is more, it should be mentioned that neither of the abbreviations of whole words were used as abbreviations of sequences of letters. Because of that classifying all abbreviations by superscript letter as abbreviations of sequences of letters instead of classifying some of them as abbreviations of whole words seems more rational from the point of view of the whole system of abbreviations in the Gospel of Matthew, especially when there are other reasons for not using superscript letters in more contexts, such as a possibility of using different abbreviations or lack of words ending with a certain sequence of letters 


\section{Source}

The Wycliffite Bible = Das neue Testament englisch. (1400). Dresden, Sächsische Landesbibliothek -Staats- und Universitätsbibliothek. Mscr.Dresd.Od.83.

\section{References}

Bischoff, B. (2012). Latin Palaeography: Antiquity and the Middle Ages. (D. Ó Cróinín \& D. Ganz, Trans.). New York, NY: Cambridge University Press. (Original work published1986).

Cappelli, A. (1982). The Elements of Abbreviation in Medieval Latin Paleography. (D. Heimann \& R. Kay, Trans.). Lawrence, KS: University of Kansas Libraries. (Original work published 1929).

Charzyńska-Wójcik, M. (2013). Text and Context in Jerome's Psalter: Prose Translations into Old, Middle and Early Modern English. Lublin: Wydawnictwo KUL.

Deanesly, M. (1920). The Lollard Bible and Other Medieval Biblical Versions. Cambridge:University Press.

Estep, W. R. (1986). Rennaissance and Reformation. Grand Rapids, MI.: William B. Eerdmans Publishing Company.

Fisher, C. (2004). Flowers in Medieval Manuscripts. Toronto: Toronto University Press.

Ghosh, K. (2004). The Wycliffite Heresy: Authority and the Interpretation of Texts. Cambridge: Cambridge University Press.

Kenyon, F.G. (1898). Our Bible and the Ancient Manuscripts. (3rd ed.). London: Eyre and Spottiswode. (Original work published 1895).

McKitterick, R. (2005). The Carolingian Renaissance of Culture and Learning. In J. Story (Ed.), Charlemagne: Empire and Society (pp. 151-166). Manchester \& New York, NY: Manchester University Press.

Metzger, B. M. (2001). The Bible in Translation. Ancient and English Versions. GrandRapids, MI: Baker Academic. Norton, D. (2000). A History of the English Bible as Literature. Cambridge: Cambridge University Press.

Olson, R. E. (1999). The Story of Christian Theology: Twenty Centuries of Tradition \&Reform. Downers Grove, IL: InterVarsity Press.

Paoli, C. (1891). Le abbreviature nella paleografia latina del medio evo: saggio metodico-pratico. Florence: Sansoni.

Poleg, E. (2013). Wycliffite Bibles as Orthodoxy. In S. Corbellini (Ed.), Instructing the Soul, Feeding the Spirit and Awakening the Passion. Cultures of Religious Reading in the Late Middle Ages (71-91). Turnhout: Brepols. 